The Open Dentistry Journal
CrossMark
Content list available at: www.benthamopen.com/TODENTJ/
DOI: $10.2174 / 1874210601610010214$

\title{
Natural Therapeutic Options in Endodontics - A Review
}

\author{
Nagendrababu Venkateshbabu, ${ }^{1, *}$, Suresh Anand ${ }^{2}$, Mohan Abarajithan ${ }^{3}$, Sultan O. Sheriff ${ }^{1}$, Pulikkotil \\ S. Jacob ${ }^{1}$ and Nath Sonia ${ }^{4}$ \\ ${ }^{I}$ Department of Restorative Dentistry, International Medical University, Kuala lumpur, Malaysia \\ ${ }^{2}$ Department of Conservative Dentistry and Endodontics, Penang International Dental College, Penang, Malaysia \\ ${ }^{3}$ Smile Bright Root Canal Academy, Madurai, India \\ ${ }^{4}$ Department of Periodontology, Vananchal Dental College, Garhwa, India
}

Received: December 30, 2015

Revised: January 10, 2016

Accepted: January 28, 2016

\begin{abstract}
Complete eradication of microbial biofilms and elimination of the smear layer are the key factors during endodontic treatment. Various chemical irrigants have been proposed in the literature for the same. The major setback with these chemical irrigants is that they are not bio-friendly to the dental and peri-radicular tissues. In the recent years, research to use natural products for root canal disinfection has gained importance. The aim of this article is to compile various herbal products that have been used as an irrigants and intracanal medicaments in the field of Endodontics to eradicate the biofilm and remove smear layer.
\end{abstract}

Keywords: Endodontics, Herbs, Intracanal medicament, Irrigants.

\section{INTRODUCTION}

The main goal of root canal treatment is to achieve maximum disinfection of the root canals, which is a challenging task owing to the complex anatomy of the root canals. The bacterial reduction is achieved partly through shaping of the canals but predominantly through irrigation and intra-canal medicaments. Irrigation is principally done to achieve the removal of intracanal smear layer, elimination of bacterial biofilms, reduction in bacterial counts and neutralising the toxins produced by microorganisms [1, 2]. The most common irrigants used are Sodium hypochlorite (NaOCl), Ethylene di amine tetra acetic acid (EDTA) solution and Chlorhexidine (CHX) [2]. The above mentioned irrigants, though effective against the pathogens, have undesirable properties. For example, $\mathrm{NaOCl}$ is toxic to the periradicular tissues [3], causes a reduction in dentin strength due to its proteolytic effect [4], has allergic potential and has an unacceptable taste and odour. $\mathrm{CHX}$ can cause staining of the tooth and forms precipitates with $\mathrm{NaOCl}$ [5].

The search for more biocompatible and dentin friendly irrigants that can overcome the limitations of these chemical antimicrobial irrigants is on the rise. Herbal products are gaining popularity in every field of medicine, mainly due to their biocompatibility [6]. The herbal extracts also possess high medicinal properties such as anti-oxidant, antimicrobial, and anti-inflammatory properties which have favoured their use in Endodontics for canal disinfection [7]. Numerous studies have been performed for the evaluation of a wide variety of natural products as an irrigant and/or intra-canal medicament. The focus of this review article is to discuss about the various herbal products that have been used for root canal disinfection.

\section{Aloe Vera (Aloe Barbadensis Miller)}

This herb belongs to the Asphodelaceae (Liliaceae) family. Aloe vera extract possesses potent antibacterial [8], antifungal [9] and antiinflammatory activity [10]. Due to its medicinal value, aloe vera has been tried in Endodontics

\footnotetext{
* Address correspondence to this author at the Department of Restorative Dentistry, International Medical University, Bukit Jalil - 57000, Kuala Lumpur, Malaysia; E-mail: venkateshbabu@imu.edu.my
} 
both as a medicament and irrigant. Bazvand et al. evaluated aloe vera as an intracanal medicament against Enterococcus faecalis in comparison with the triantibiotic paste, $\mathrm{CHX}$ gel and propolis. He observed that though aloe vera was effective against E. faecalis, it was not as effective as the triantibiotic paste and CHX gel [11]. Sahebi et al. evaluated the antibacterial efficacy of aloe vera as an irrigant in comparison with $2.5 \% \mathrm{NaOCl}$. They also reported that aloe vera was not effective against E. faecalis and hence did not recommend it as an irrigant [12]. Bharadwaj et al. also reported that even after ultrasonic activation, aloe vera was not effective against $E$. faecalis biofilms [13].

\section{Bee Glue (Propolis)}

It is a natural antibiotic extracted from the honey bees [7]. Propolis has been used in dentistry owing to its antioxidant [14], antimicrobial [15, 16] and anti-inflammatory [17] properties. It has been tried for dentin disinfection in root canal treatment. Carbajal, study proved that in comparison with $2 \% \mathrm{CHX}$ and calcium hydroxide $\left(\mathrm{Ca}(\mathrm{OH})_{2}\right)$, propolis possessed equally good antibacterial efficacy against E. faecalis; however, its antifungal efficacy was less [18]. The antimicrobial properties might be attributed to the presence of flavonoids. Other studies have also found promising results against both C. albicans and E. faecalis biofilms in comparison with other natural irrigants and $\mathrm{NaOCl}$ [19 - 21].

\section{Burdock (Arctium Lappa)}

It is commonly known as the Greater burdock. It has been popularly used in traditional Chinese medicine [22]. Gentil et al. [23] compared the antibacterial activity of ethyl acetate fraction extracted from Arctium lappa with $\mathrm{Ca}(\mathrm{OH})_{2}$. They concluded that $A$. lappa inhibited the growth of all the microorganisms. The constituents of $A$. lappa was shown to have antimicrobial activity against the common endodontic microorganisms (Candida albicans, Enterococcus faecalis, Staphylococcus aureus, Bacillus subtilis and Pseudomonas aeruginosa) [24].

\section{Cinnamon (Cinnamomum zeylanicum)}

It belongs to the Lauraceae family. It has been commonly named as the cinnamon tree, cinnamon, Ceylon celonzimi cinnamon, cinnamon bark, blood-giving drops and cortex cinnamomi [25]. Cinnamon has been shown to have antibacterial efficacy against both E. faecalis and S. mutans [26]. Gupta et al. compared the antimicrobial efficacy of Cinnamomum zeylanicum with Ocimum sanctum, Syzygium aromaticum and $\mathrm{NaOCl}$ against both the forms (Planktonic form and biofilm) of E. faecalis. They proved that $\mathrm{NaOCl}$ had better efficacy, followed by herbal products. C. zeylanicum and S. aromaticum showed better antimicrobial efficacy when compared to O. sanctum. The antimicrobial effect has been attributed to the presence of essential oils like eugenol in the cinnamon extract and membrane disruption has been proposed to be the mechanism of action [27].

\section{Copaiba Oil}

Copaiba commonly known as turpentine is an oleoresin derived from the trunk of leguminous trees (Genus Copaifera). The exudate which is thick and transparent is found to have anti-bacterial [28] and anti-tumour activity [29]. Piovesani et al. demonstrated that though copaiba oil was not completely effective against E. faecalis, it did possess antibacterial efficacy when compared with propolis, $\mathrm{Ca}(\mathrm{OH})_{2}$ and $\mathrm{CHX}$ [30]. The mechanism of action claimed for its antibacterial efficacy is its direct breaking action on the cell wall of bacteria resulting in a release of the cytoplasmic components. Copaiba oil has been incorporated into a sealer (Biosealer) and its cytotoxic properties have been proved to be mild when compared to AH-plus and Endofill [31]. This Copaifera multijuga oil-resin (Biosealer) showed ADA acceptable levels of property in terms of flow, solubility, dimensional stability and film thickness [32].

\section{Ferula Gummosa}

It grows widely in central Asia, Mediterranean regions and Northern Africa [33, 34]. Its medicinal properties include antimicrobial, antinociceptive, antiinflammatory, anticonvulsant, antioxidant and antispasmodic activities [35 40] Abbaszadegan et al. compared the antimicrobial efficacy of Ferula gummosa essential oil with $\mathrm{NaOCl}$ and $\mathrm{CHX}$. They proved that Ferula gummosa essential oil was effective against E. faecalis than $\mathrm{NaOCl}$ and $\mathrm{CHX}$ and it was better than $\mathrm{CHX}$ against $C$. albicans and $S$. aureus. The antimicrobial activity might be attributed due to the presence of $\beta$ pinene and $\alpha$-pinene [41]

\section{Garlic (Allium Sativum)}

Garlic has antimicrobial [42], anticancer [43] and antiplatelet activity [44]. Eswar et al. [45] investigated the 
efficacy of Garlic against E. faecalis. Garlic showed better antibacterial efficacy compared to $\mathrm{Ca}(\mathrm{OH})_{2}$ and performed less when compared to $2 \% \mathrm{CHX}$. The antibacterial efficacy can be due to the presence of allicin, an organosulphur compound in garlic $[45,46]$.

\section{German Chamomile (Marticaria Recutita)}

It has antimicrobial [47], antioxidant [47], antiinflammatory [48], antihyperalgesic [49] and antiedematous [49] activity. Lahijani et al. [50] compared the chamomile hydroalcoholic extract and tea tree oil to $2.5 \% \mathrm{NaOCl}$ for smear layer removal. They concluded that chamomile has the ability to remove the smear layer better when compared to $\mathrm{NaOCl}$, but lesser than the combination of $\mathrm{NaOCl}$ and EDTA. The smear layer removal could be attributed due to the presence of acidic components (capric acid, caprylic acid, chlorogenic acid, o-caumaric acid, p-caumaricacid, dihydroxybenzoic acid) in the extract $[50,51]$

\section{Ginger (Zingiber Officinale)}

It belongs to Zingiberaceae family and it has also been used as a medicine from Vedic days due to its antibacterial and antifungal properties. [52, 53] Maekawa et al. evaluated the antimicrobial efficacy of Glycolic propolis, ginger extract, $\mathrm{Ca}(\mathrm{OH})_{2}, \mathrm{CHX}$ and their combinations against E. faecalis, C. albicans, Escherichia coli and endotoxins in root canals. The ginger extract used in this study, was the dehydrated rhizome of Zingiber officinale Roscoe, which contains flavonoids, with $1.50 \mathrm{mg} / \mathrm{mL}$ being the minimum standard for the whole extract. It was observed that this extract was effective in eliminating the microorganisms from the root canals. [54]

\section{Grapefruit (Citrus Paradisi)}

Grapefruit extract is derived from the seeds and pulp of grapefruit. It has antimicrobial [55 - 57], antiplatelet [58] and antioxidant $[59,60]$ property. Rees et al. observed that Grape fruit seed extract was able to remove the smear layer. This was considered to be an important property in enhancing the patency of dentinal tubules [61].

\section{Green Tea (Camellia Sinesis)}

It is the most widely consumed beverage. It has antibacterial [62, 63], antifungal [64], antioxidant [62] and antiinflammatory [65] properties. Prabhakar et al. [66] evaluated the antimicrobial efficacy of Triphala, Green tea polyphenols and $\mathrm{NaOCl}$ on E. faecalis biofilms. They observed that $\mathrm{NaOCl}$ had the maximum antibacterial activity followed by Triphala and green tea. The properties of Green tea might be due to its flavonoid content by inhibition of bacterial enzyme gyrase by binding to Adenosine triphosphate B sub unit [67]. Epigallocatechin-3-gallate (EGCG) is the most abundant polyphenol in green tea. Lee and Tan evaluated the effects of EGCG against E. faecalis biofilm and its virulence. They concluded that EGCG is an effective antimicrobial agent against E. faecalis and its antimicrobial action might be due to the production of hydroxyl radicals [68].

\section{Gum (Acacia Nilotica)}

It is an Arabic tree, Babul, Egyptian thor. [69] Its medicinal properties include antimicrobial [70], antifungal [71], antiviral [72], antibiotic [73], anticancer [74], and antiplatelet activity [75]. Pai et al. [76] compared antifungal efficacy of Acacia nilotica with other natural extracts against $C$. albicans. The efficacy of the extracts were in the following order: Tunica granatum, Acacia nilotica, Foeniculum vulgare, Cuminum cyminum. It contains Methyl gallate, which possesses antimicrobial activity by altering the DNA system by a Ferric - Bleomycin system [77].

\section{Key Lime (Citrus Aurantifolia)}

It has antibacterial [78], antifungal [78] and antioxidant [79] properties. Bolhari et al. found that the extract of Citrus aurantifolia (CA) was not able to effectively remove the smear layer when compared to 17\% EDTA. It consists of $6-8 \%$ of citric acid which could have probably helped in the removal of the smear layer [80].

\section{Liquorice (Glycyrrhiza Glabra)}

It is a sweet, soothing herb [81] and is useful in the treatment of dermatitis, eczema and herpes [81 - 84]. Badr et al. [85] investigated the efficacy of liquorice when used as an intracanal medicament. It has been shown that liquorice extract, either by itself or with $\mathrm{Ca}(\mathrm{OH})_{2}$ had a significant effect against E. faecalis compared with that of $\mathrm{Ca}(\mathrm{OH})_{2}$ alone. The reason for its antibacterial efficacy is due to the presence of glycyrrhizin [86]. 


\section{Mango (Mangifera Indica)}

Mangiferin, a major C-glucosyl xanthone is found in the M. indica stem bark, leaves, roots and fruits [87, 88]. The antibacterial activity of mango kernel may be attributed to the tannins present in them. [87]. Subbiya et al. [89] compared the antibacterial efficacy of Mangifera indica L. kernel and Ocimum sanctum L. leaves (tulsi) extracts with $\mathrm{NaOCl}$ and $\mathrm{CHX}$ against E.faecalis biofilm. Mango kernel showed higher zone of inhibition when compared to the other herbs [89].

\section{Myrobolan (Terminalia Chebula)}

The beneficial effects of Myrobolan includes antimicrobial activity [90, 91] anticaries agent [92] and antioxidant properties [93]. Vinothkumar et al. [94] evaluated the efficacy of herbal extracts against E.faecalis and C.albicans. The efficiency of extracts was in the following order: Aloevera, Terminalia chebula, Myristica fragrans, Curcuma longa and Azadiracta indica. The active ingredient, tannin is responsible for its antimicrobial activity.

\section{Myrtle (Myrtus Communis)}

It is a small ever green tree of the Myrtaceae family with aromatic and medicinal properties. Various parts of this herb (berries, leaves and fruits) have been used as a folk medicine [95]. It has antibacterial [95, 96], antifungal [95, 97], antioxidant [95, 98, 99], antiinflammatory [95, 100], anticancer [101] and antidiabetic [102] properties. Nabavizadeh et al. investigated the antimicrobial activity against persistent endodontic infections (S.aureus, E. faecalis, and C. albicans) [103]. M.communis leaves showed antimicrobial activity against organisms with MIC values in the range of $0.032-32 \mu \mathrm{g} / \mathrm{mL}$. They also assessed the chemical composition of the essential oils of M. communis. The main constituents of the essential oil were 1, 8-cineole (28.62\%), $\alpha$-pinene (17/8\%), and linalool (17.53\%), which could be the reason for the antibacterial efficacy of the extract [104].

\section{Neem (Azadirachta Indica)}

It is also known as the margosa tree or Indian neem [105]. Neem is considered as the most important medicinal plant in naturopathy. The isoprenoid group of constituents of neem have antiinflammatory [106], antibacterial [107], antifungal [108] and immunomodulatory properties [109]. Among the extracts from different parts of the neem tree, maximum antibacterial efficacy was demonstrated for the extract from the leaf [110]. Due to its promising antibacterial efficacy, it has been tried both as an irritant and medicament for the disinfection of infected root canals. Dutta and Kundabala in their study assessed the reduction in bacterial load using anaerobic culture method in infected root canals and found that the combination of $\mathrm{NaOCl}$ and neem irrigant produced the maximum reduction in bacterial loads [111]. Mistry et al. evaluated the antimicrobial activity of Azadirachta indica, Ocimum sanctum, Mimusops elelngi, Tinospora cardifolia and CHX against $S$ mutans, $S$ aureus and E faecalis. The methanolic extracts of the irrigants were studied using the agar diffusion test. Even at a lower concentration $(3 \mathrm{mg})$, neem was effective against S.mutans and S.aureus; however, it was effective against $E$. faecalis only at higher concentrations (50\%) [112]. Vinoth Kumar et al. evaluated the antimicrobial efficacy of Curcuma longa, Aloe barbadensis, Azadiracta indica, Myristica fragrans and Terminalia chebula as an endodontic irrigant against $E$. faecalis and $C$. albicans. They found that neem was highly efficient when compared to other natural irrigants against both the organisms [94]. The antibacterial properties of neem are due to the various active phytoconstituents such as alkaloids, glycosides, terpenoids, steroids and tannins [113].

\section{Noni plant (Morinda Citrifolia)}

It belongs to the Rubiaceae family. It has analgesic, antimicrobial and anticancer effects [114 - 117]. Murray et al. [118] investigated the smear layer removing ability of $6 \%$ Morinda citrifolia juice (MCJ) compared to $\mathrm{NaOCl}$ and CHX. They proved that when MCJ, when used in combination with EDTA, performed equal to $\mathrm{NaOCl}$ and better than $\mathrm{CHX}$, in removing the smear layer. The $\mathrm{MCJ}$ can be an alternate irrigant for $\mathrm{NaOCl}$, as an initial rinse. The MCJ has antimicrobial efficacy against $E$. faecalis, which could be attributed to the presence of L-asperuloside, alizarin, acubin and scopoletin [20,67, 117]. Das et al. [119] compared the effect of microhardness of the dentin when treated with MCJ and Q mix. They showed that Q Mix regimen did not hamper the micro hardness when compared to MCJ.

\section{Nutmeg (Myristica Fragrans)}

It produces two spices - nutmeg and mace. It has antifungal [120], antibacterial [121], antidepressant [122], antidiabetic [123], antioxidant [124] and antiangiogenic activity [116]. It exerts an antimicrobial effect against $E$. 
faecalis and $C$ albicans. The reason for the antimicrobial efficacy might be due to the presence of myristic acid [94].

\section{Passion Fruit (Passiflora Edulis)}

It has been used widely in folk medicine in South America. The constituents of different extracts include flavonoids, alkaloids, cyanogenic compounds, glycosides, vitamins, minerals and terpenoid compounds [125]. It has antibacterial, antifungal [126], antihypertensive [127] and antiinflammatory properties [128]. The ability of the passion fruit juice (PFJ) to remove smear layer has also been proven by Rees et al. [61]. Jayahari et al. [129] assessed the effectiveness of various concentrations of two forms of the passion fruit juice in the elimination of E. faecalis. They have also compared the antibacterial property of $\mathrm{PFJ}$ with $\mathrm{NaOCl}$, as an irrigant. They concluded that broth dilution test showed a negative growth of E. faecalis by PFJ alcohol $20 \%$ at 30 min, PFJ aqueous $20 \%$ at $1 \mathrm{~h}$; however, $\mathrm{NaOCl}$ showed much better antibacterial efficacy.

\section{Triphala}

Triphala is a powder that consists of equal parts of Emblica officinalis, Terminalia chebula, and Terminalia belerica [130]. In dentistry, it has been used because of their antimicrobial [131, 132], antiplaque [133], antigingivitis [133], anticariogenic [134] and anti-collagenase properties [135]. Shakouie et al. compared the antimicrobial efficacy of triphala with various concentrations of $\mathrm{NaOCl}$ against E. faecalis and reported that triphala exhibited better antimicrobial activity against $E$. faecalis when compared to 0.5 and $1 \% \mathrm{NaOCl}$ [131].

\section{Tulsi (Ocimum Sanctum)}

It is traditionally used as a medicinal plant. It has antimicrobial [136], antidiabetic [137], and anticancer [138] properties. Gupta et al. [27] compared the antimicrobial efficacy of Syzygium aromaticum, Ocimum sanctum and Cinnamomum zeylanicum plant extracts against E. faecalis. They concluded that Cinnamomum zeylanicum, S. aromaticum and $O$. sanctum demonstrated antimicrobial activity against E.faecalis. O. sanctum showed less efficacy compared to $C$. zeylanicum and $S$. aromaticum. The antimicrobial property might be due to the presence of tannins and essential oils (eugenol and methyleugenol) [27]. The reduced efficacy of O.sanctum as compared to other groups in this study might be attributed to the lower concentration of active ingredients. But they stated that there was no direct evidence related to this hypothesis.

\section{Turmeric (Curcuma Longa)}

It is a popular spice and food preservative used commonly as a medicine in India, China and countries of South East Asia. It has antimicrobial [139], antiinflammatory [140] and antioxidant [140] and antitumour [141] activity. The main bioactive ingredient is Curcumin (diferuloylmethane) in turmeric [139, 142]. In an in vitro study on human extracted teeth, curcumin was as efficacious as $\mathrm{NaOCl}$, but superior to $\mathrm{CHX}$ in eradicating E.faecalis biofilms [143]. Curcumin was recommended in support of its desirable non-toxic properties in comparison to $\mathrm{NaOCl}$. Curcumin also has been found to be a better disinfectant against E.faecalis both in its planktonic and biofilm forms when used as a blue light photosensitizers [144]. However, curcumin did not show any toxicity against odontoblast-like cells, undifferentiated pulp cells and human embryonic stem cells [145]. Praveenkumar et al. found Curcumin to be efficacious against Streptococcus mutans, Actinomyces viscosus, Lactobacillus casei, Porphyromonas gingivalis and Prevotella intermedia in an in vitro model [146]. Photoactivated curcumin had the ability to eliminate the E. faecalis biofilm within root canal walls [147].

\section{Zataria Multiflora}

It is a natural thyme-like plant with chemical and pharmacological properties [148]. Abbaszadegan et al. studied essential oils of Z. multiflora with that of Aloe vera and $\mathrm{Ca}(\mathrm{OH})_{2}$ against E.faecalis. He concluded that essential oils of Z. Multiflora eliminated E.facealis similar to that of Aloe vera and $\mathrm{Ca}(\mathrm{OH})_{2}$ at the end of 14 days [149]. The antimicrobial activity might be due to the presence of thymol and carvacrol. They act on the cell membrane of the organisms and results in cell lysis [149].

\section{CONCLUSION}

The research focus is increasing more towards natural products for root canal disinfection owing to their inherent properties like easy availability, cost-effectiveness, increased shelf life and low toxicity. Although only a few of the 
natural products have been shown to have promising results. More combinations and various concentrations may improve their efficacy and usage for root canal disinfection in a bio-friendly way. Further animal model and in vivo studies has to be done to evaluate the effect of natural extracts on the long term prognosis of root canal treatment.

\section{CONFLICT OF INTEREST}

The authors confirm that this article content has no conflict of interest.

\section{ACKNOWLEDGEMENTS}

Declared none.

\section{REFERENCES}

[1] Mohammadi Z, Soltani MK, Shalavi S. An update on the management of endodontic biofilms using root canal irrigants and medicaments. Iran Endod J 2014; 9(2): 89-97. [PMID: 24688576]

[2] Zehnder M. Root canal irrigants. J Endod 2006; 32(5): 389-98. [http://dx.doi.org/10.1016/j.joen.2005.09.014] [PMID: 16631834]

[3] Motta MV, Chaves-Mendonca MA, Stirton CG, Cardozo HF. Accidental injection with sodium hypochlorite: report of a case. Int Endod J 2009; 42(2): 175-82.

[http://dx.doi.org/10.1111/j.1365-2591.2008.01493.x] [PMID: 19134046]

[4] Pascon FM, Kantovitz KR, Sacramento PA, Nobre-dos-Santos M, Puppin-Rontani RM. Effect of sodium hypochlorite on dentine mechanical properties. A review. J Dent 2009; 37(12): 903-8. [http://dx.doi.org/10.1016/j.jdent.2009.07.004] [PMID: 19665276]

[5] Ryan S. Chlorhexidine as a canal irrigant: a review. Compend Contin Educ 2010; 31(12): 338-42.

[6] Li L, Zhou X, Li N, Sun M, Lv J, Xu Z. Herbal drugs against cardiovascular disease: traditional medicine and modern development. Drug Discov Today 2015; 20(9): 1074-86.

[http://dx.doi.org/10.1016/j.drudis.2015.04.009] [PMID: 25956424]

[7] Ravishankar P, Lakshmi T, Kumar SA. Ethno-Botanical approach for root canal treatment- an update. J Pharm Sci \& Res 2011 ; 3: 1511-9.

[8] Maguire H, Torabinejad M, Kettering J. The use of aloe vera gel as an intracanal medicament. J Endod 1996; $22: 193$. [http://dx.doi.org/10.1016/S0099-2399(96)80120-8]

[9] Das S, Mishra B, Gill K, et al. Isolation and characterization of novel protein with anti-fungal and anti-inflammatory properties from Aloe vera leaf gel. Int J Biol Macromol 2011; 48(1): 38-43.

[10] Hutter JA, Salman M, Stavinoha WB, et al. Antiinflammatory C-glucosyl chromone from Aloe barbadensis. J Nat Prod 1996; 59(5): 541-3. [http://dx.doi.org/10.1021/np9601519] [PMID: 8778246]

[11] Bazvand L, Aminozarbian MG, Farhad A, Noormohammadi H, Hasheminia SM, Mobasherizadeh S. Antibacterial effect of triantibiotic mixture, chlorhexidine gel, and two natural materials Propolis and Aloe vera against Enterococcus faecalis: An ex vivo study. Dent Res J (Isfahan) 2014; 11(4): 469-74.

[PMID: 25225560]

[12] Sahebi S, Khosravifar N, Sedighshamsi M, Motamedifar M. Comparison of the antibacterial effect of sodium hypochlorite and aloe vera solutions as root canal irrigants in human extracted teeth contaminated with enterococcus faecalis. J Dent (Shiraz) 2014; 15(1): 39-43. [PMID: 24738089]

[13] Bhardwaj A, Velmurugan N, Ballal S. Efficacy of passive ultrasonic irrigation with natural irrigants (Morinda citrifolia juice, Aloe Vera and Propolis) in comparison with $1 \%$ sodium hypochlorite for removal of E. faecalis biofilm: an in vitro study. Indian J Dent Res 2013; 24(1): 35-41.

[http://dx.doi.org/10.4103/0970-9290.114938] [PMID: 23852230]

[14] Krol W, Czuba Z, Scheller S, Gabrys J, Grabiec S, Shani J. Anti-oxidant property of ethanolic extract of propolis (EEP) as evaluated by inhibiting the chemiluminescence oxidation of luminol. Biochem Int 1990; 21(4): 593-7. [PMID: 2241984]

[15] Ikeno K, Ikeno T, Miyazawa C. Effects of propolis on dental caries in rats. Caries Res 1991; 25(5): $347-51$. [http://dx.doi.org/10.1159/000261390] [PMID: 1836157]

[16] Parolia A, Thomas MS, Kundabala M, Mohan M. Propolis and its potential uses in oral health. Int J Med Medical Sci 2010; 2: 210-5.

[17] Borrelli F, Maffia P, Pinto L, et al. Phytochemical compounds involved in the anti-inflammatory effect of propolis extract. Fitoterapia 2002; 73(Suppl. 1): S53-63. [http://dx.doi.org/10.1016/S0367-326X(02)00191-0] [PMID: 12495710]

[18] Carbajal Mejía JB. Antimicrobial effects of calcium hydroxide, chlorhexidine, and propolis on Enterococcus faecalis and Candida albicans. J Investig Clin Dent 2014; 5(3): 194-200. 
[http://dx.doi.org/10.1111/jicd.12041] [PMID: 23559565]

[19] Bhandari S, T S A, Patil CR. An in Vitro Evaluation of Antimicrobial Efficacy of 2\% Chlorhexidine Gel, Propolis and Calcium Hydroxide Against Enterococcus faecalis in Human Root Dentin. J Clin Diagn Res 2014; 8(11): ZC60-3. [PMID: 25584319]

[20] Kandaswamy D, Venkateshbabu N, Gogulnath D, Kindo AJ. Dentinal tubule disinfection with 2\% chlorhexidine gel, propolis, morinda citrifolia juice, $2 \%$ povidone iodine, and calcium hydroxide. Int Endod J 2010; 43(5): 419-23. [http://dx.doi.org/10.1111/j.1365-2591.2010.01696.x] [PMID: 20518935]

[21] Tyagi SP, Sinha DJ, Garg P, Singh UP, Mishra CC, Nagpal R. Comparison of antimicrobial efficacy of propolis, Morinda citrifolia, Azadirachta indica (Neem) and 5\% sodium hypochlorite on Candida albicans biofilm formed on tooth substrate: An in-vitro study. J Conserv Dent 2013; 16(6): 532-5.

[http://dx.doi.org/10.4103/0972-0707.120973] [PMID: 24347888]

[22] Chan YS, Cheng LN, Wu JH, et al. A review of the pharmacological effects of Arctium lappa (burdock). Inflammopharmacology 2011; 19(5): 245-54. [http://dx.doi.org/10.1007/s10787-010-0062-4] [PMID: 20981575]

[23] Gentil M, Pereira JV, Sousa YT, et al. In vitro evaluation of the antibacterial activity of Arctium lappa as a phytotherapeutic agent used in intracanal dressings. Phytother Res 2006; 20(3): 184-6. [http://dx.doi.org/10.1002/ptr.1829] [PMID: 16521107]

[24] Pereira JV, Bergamo DC, Pereira JO, França SdeC, Pietro RC, Silva-Sousa YT. Antimicrobial activity of Arctium lappa constituents against microorganisms commonly found in endodontic infections. Braz Dent J 2005; 16(3): 192-6. [http://dx.doi.org/10.1590/S0103-64402005000300004] [PMID: 16429183]

[25] World Health Organization. WHO Monographs On Selected Medicinal Plants. Geneva, Switzerland: WHO 1999; 1: pp. 95-104.

[26] Khan R, Islam B, Akram M, et al. Antimicrobial activity of five herbal extracts against multi drug resistant (MDR) strains of bacteria and fungus of clinical origin. Molecules 2009; 14(2): 586-97.

[http://dx.doi.org/10.3390/molecules14020586] [PMID: 19214149]

[27] Gupta A, Duhan J, Tewari S, et al. Comparative evaluation of antimicrobial efficacy of Syzygium aromaticum, Ocimum sanctum and Cinnamomum zeylanicum plant extracts against Enterococcus faecalis: a preliminary study. Int Endod J 2013; 46(8): 775-83. [http://dx.doi.org/10.1111/iej.12058] [PMID: 23506110]

[28] Santos AO, Ueda-Nakamura T, Dias Filho BP, Veiga Junior VF, Pinto AC, Nakamura CV. Antimicrobial activity of Brazilian copaiba oils obtained from different species of the Copaifera genus. Mem Inst Oswaldo Cruz 2008; 103(3): 277-81. [http://dx.doi.org/10.1590/S0074-02762008005000015] [PMID: 18545856]

[29] Tsuboy MS, Marcarini JC, Luiz RC, et al. In vitro evaluation of the genotoxic activity and apoptosis induction of the extracts of roots and leaves from the medicinal plant Coccoloba mollis (Polygonaceae). J Med Food 2010; 13(3): 503-8. [http://dx.doi.org/10.1089/jmf.2009.0119] [PMID: 20438324]

[30] Piovesani JF, Semenoff-Segundo A, Pedro F, et al. Antibacterial Capacity of Different Intracanal Medications on Enterococcus Faecalis. Dental Press Endod 2012; 2: 53-8.

[31] Garrido AD, de Cara SP, Marques MM, Sponchiado EC Jr, Garcia LdaF, de Sousa-Neto MD. Cytotoxicity evaluation of a copaiba oil-based root canal sealer compared to three commonly used sealers in endodontics. Dent Res J (Isfahan) 2015; 12(2): 121-6. [PMID: 25878676]

[32] Garrido AD, Lia RC, França SC, da Silva JF, Astolfi-Filho S, Sousa-Neto MD. Laboratory evaluation of the physicochemical properties of a new root canal sealer based on Copaifera multijuga oil-resin. Int Endod J 2010; 43(4): 283-91. [http://dx.doi.org/10.1111/j.1365-2591.2009.01678.x] [PMID: 20487447]

[33] Mozaffarian V. The family of Umbelliferae in Iran: keys and distribution. Ministry of Agriculture. In: Research Organization of Agriculture and Natural Resources, Research Institute of Forest and Rangelands ; Tehran. 1983. 387 p-illus, keys En (Pe) Icones Geog 2.

[34] Evans WC. Trease and Evans' pharmacognosy. $16^{\text {th }}$ ed. London: Elsevier Health Sciences 2009.

[35] Sadraei H, Asghari GR, Hajhashemi V, Kolagar A, Ebrahimi M. Spasmolytic activity of essential oil and various extracts of Ferula gummosa Boiss. on ileum contractions. Phytomedicine 2001; 8(5): 370-6.

[http://dx.doi.org/10.1078/0944-7113-00052] [PMID: 11695880]

[36] Sayyah M, Mandgary A, Kamalinejad M. Evaluation of the anticonvulsant activity of the seed acetone extract of Ferula gummosa Boiss. against seizures induced by pentylenetetrazole and electroconvulsive shock in mice. J Ethnopharmacol 2002; 82(2-3): 105-9. [http://dx.doi.org/10.1016/S0378-8741(02)00166-6] [PMID: 12241984]

[37] Eftekhar F, Yousefzadi M, Borhani K. Antibacterial activity of the essential oil from Ferula gummosa seed. Fitoterapia 2004; 75(7-8): 758-9. [http://dx.doi.org/10.1016/j.fitote.2004.09.004] [PMID: 15567258]

[38] Mandegary A, Sayyah M, Heidari MR. Antinociceptive and anti-inflammatory activity of the seed and root extracts of Ferula gummosa Boiss in mice and rats. DARU J Pharmaceut Sci 2004; 12: 58-62.

[39] Ghasemi Y, Faridi P, Mehregan I, Mohagheghzadeh A. Ferula gummosa Fruits: An Aromatic Antimicrobial Agent. Chem Nat Compd 2005; 41: 311-4. [http://dx.doi.org/10.1007/s10600-005-0138-3] 
[40] Fazel Nabavi S, Ebrahimzadeh MA, Mohammad Nabavi S, Eslami B. Antioxidant activity of flower, stem and leaf extracts of Ferula gummosa Boiss. Grasas Aceites 2010; 61: 244-50. [http://dx.doi.org/10.3989/gya.110809]

[41] Abbaszadegan A, Gholami A, Mirhadi H, Saliminasab M, Kazemi A, Moein MR. Antimicrobial and cytotoxic activity of Ferula gummosa plant essential oil compared to $\mathrm{NaOCl}$ and $\mathrm{CHX}$ : a preliminary in vitro study. Restor Dent Endod 2015; 40(1): 50-7. [http://dx.doi.org/10.5395/rde.2015.40.1.50] [PMID: 25671213]

[42] Shetty S, Thomas B, Shetty V, Bhandary R, Shetty RM. An in-vitro evaluation of the efficacy of garlic extract as an antimicrobial agent on periodontal pathogens: A microbiological study. Ayu 2013; 34(4): 445-51. [http://dx.doi.org/10.4103/0974-8520.127732] [PMID: 24695825]

[43] Milner JA. Garlic: its anticarcinogenic and antitumorigenic properties. Nutr Rev 1996; 54(11 Pt 2): S82-6 [PMID: 9110580]

[44] Vilahur G, Badimon L. Antiplatelet properties of natural products. Vascul Pharmacol 2013; 59(3-4): 67-75. [http://dx.doi.org/10.1016/j.vph.2013.08.002] [PMID: 23994642]

[45] Eswar K, Venkateshbabu N, Rajeswari K, Kandaswamy D. Dentinal tubule disinfection with 2\% chlorhexidine, garlic extract, and calcium hydroxide against Enterococcus faecalis by using real-time polymerase chain reaction: In vitro study. J Conserv Dent 2013; 16(3): 194-8. [http://dx.doi.org/10.4103/0972-0707.111312] [PMID: 23833449]

[46] Feldberg RS, Chang SC, Kotik AN, et al. In vitro mechanism of inhibition of bacterial cell growth by allicin. Antimicrob Agents Chemother 1988; 32(12): 1763-8 [http://dx.doi.org/10.1128/AAC.32.12.1763] [PMID: 2469386]

[47] Munir N, Iqbal AS, Altaf I, et al. Evaluation of antioxidant and antimicrobial potential of two endangered plant species Atropa belladonna and Matricaria chamomilla. Afr J Tradit Complement Altern Medicines 2014; 11(5): 111-7. [http://dx.doi.org/10.4314/ajtcam.v11i5.18] [PMID: 25395714]

[48] Dell'Agli M, Di Lorenzo C, Badea M, et al. Plant food supplements with anti-inflammatory properties: a systematic review (I). Crit Rev Food Sci Nutr 2013; 53(4): 403-13.

[http://dx.doi.org/10.1080/10408398.2012.682123] [PMID: 23320910]

[49] Tomić M, Popović V, Petrović S, et al. Antihyperalgesic and antiedematous activities of bisabolol-oxides-rich matricaria oil in a rat model of inflammation. Phytother Res 2014; 28(5): 759-66. [http://dx.doi.org/10.1002/ptr.5057] [PMID: 23983133]

[50] Sadr Lahijani MS, Raoof Kateb HR, Heady R, Yazdani D. The effect of German chamomile (Marticaria recutita L.) extract and tea tree (Melaleuca alternifolia L.) oil used as irrigants on removal of smear layer: a scanning electron microscopy study. Int Endod J 2006; 39(3): 190-5.

[http://dx.doi.org/10.1111/j.1365-2591.2006.01073.x] [PMID: 16507072]

[51] Avallone R, Zanoli P, Puia G, Kleinschnitz M, Schreier P, Baraldi M. Pharmacological profile of apigenin, a flavonoid isolated from Matricaria chamomilla. Biochem Pharmacol 2000; 59(11): 1387-94. [http://dx.doi.org/10.1016/S0006-2952(00)00264-1] [PMID: 10751547]

[52] Panchajanya S. An in-vitro evaluation of antibacterial activity of medicinal plants and calcium hydroxide against enterococcus. Indian J Dent Sci 2014; 6 .

[53] Chopra RN, Chopra IC, Varma IC. Supplement to glossary of Indian medicinal plant India: Council of Scientific \& Industrial Research 1969.

[54] Maekawa LE, Valera MC, Oliveira LD, Carvalho CA, Camargo CH, Jorge AO. Effect of Zingiber officinale and propolis on microorganisms and endotoxins in root canals. J Appl Oral Sci 2013; 21(1): 25-31. [http://dx.doi.org/10.1590/1678-7757201302129] [PMID: 23559108]

[55] Kanmani P, Rhim JW. Antimicrobial and physical-mechanical properties of agar-based films incorporated with grapefruit seed extract. Carbohydr Polym 2014; 102: 708-16. [http://dx.doi.org/10.1016/j.carbpol.2013.10.099] [PMID: 24507339]

[56] Heggers JP, Cottingham J, Gusman J, et al. The effectiveness of processed grapefruit-seed extract as an antibacterial agent: II. Mechanism of action and in vitro toxicity. J Altern Complement Med 2002; 8(3): 333-40. [http://dx.doi.org/10.1089/10755530260128023] [PMID: 12165191]

[57] Cvetnić Z, Vladimir-Knezević S. Antimicrobial activity of grapefruit seed and pulp ethanolic extract. Acta Pharm 2004; 54(3): 243-50. [PMID: 15610620]

[58] Taniguchi K, Ohtani H, Ikemoto T, Miki A, Hori S, Sawada Y. Possible case of potentiation of the antiplatelet effect of cilostazol by grapefruit juice. J Clin Pharm Ther 2007; 32(5): 457-9. [http://dx.doi.org/10.1111/j.1365-2710.2007.00844.x] [PMID: 17875111]

[59] Proteggente AR, Pannala AS, Paganga G, et al. The antioxidant activity of regularly consumed fruit and vegetables reflects their phenolic and vitamin C composition. Free Radic Res 2002; 36(2): 217-33. [http://dx.doi.org/10.1080/10715760290006484] [PMID: 11999391]

[60] Kabir F, Tow WW, Hamauzu Y, Katayama S, Tanaka S, Nakamura S. Antioxidant and cytoprotective activities of extracts prepared from fruit and vegetable wastes and by-products. Food Chem 2015; 167: 358-62. 
[http://dx.doi.org/10.1016/j.foodchem.2014.06.099] [PMID: 25148998]

[61] Rees JS, Loyn T, Rowe W, Kunst Q, McAndrew R. The ability of fruit teas to remove the smear layer: an in vitro study of tubule patency. J Dent 2006; 34(1): 67-76.

[http://dx.doi.org/10.1016/j.jdent.2005.03.006] [PMID: 15982795]

[62] Bashir S, Khan BM, Babar M, et al. Assessment of bioautography and spot screening of TLC of green tea (Camellia) plant extracts as antibacterial and antioxidant agents. Indian J Pharm Sci 2014; 76(4): 364-70. [PMID: 25284935]

[63] Anita P, Sivasamy S, Madan Kumar PD, Balan IN, Ethiraj S. In vitro antibacterial activity of Camellia sinensis extract against cariogenic microorganisms. J Basic Clin Pharm 2014; 6(1): 35-9. [http://dx.doi.org/10.4103/0976-0105.145777] [PMID: 25538470]

[64] Betts JW, Wareham DW, Haswell SJ, Kelly SM. Antifungal synergy of theaflavin and epicatechin combinations against Candida albicans. J Microbiol Biotechnol 2013; 23(9): 1322-6. [http://dx.doi.org/10.4014/jmb.1303.03010] [PMID: 23711519]

[65] Watson JL, Vicario M, Wang A, Moreto M, McKay DM. Immune cell activation and subsequent epithelial dysfunction by Staphylococcus enterotoxin B is attenuated by the green tea polyphenol(-)-epigallocatechin gallate. Cell Immunol 2005; 237(1): 7-16. [http://dx.doi.org/10.1016/j.cellimm.2005.08.030] [PMID: 16213476]

[66] Prabhakar J, Senthilkumar M, Priya MS, Mahalakshmi K, Sehgal PK, Sukumaran VG. Evaluation of antimicrobial efficacy of herbal alternatives (Triphala and green tea polyphenols), MTAD, and 5\% sodium hypochlorite against Enterococcus faecalis biofilm formed on tooth substrate: an in vitro study. J Endod 2010; 36(1): 83-6. [http://dx.doi.org/10.1016/j.joen.2009.09.040] [PMID: 20003940]

[67] Rosaline H, Kandaswamy D, Gogulnath D, Rubin M. Influence of various herbal irrigants as a final rinse on the adherence of Enterococcus faecalis by fluorescence confocal laser scanning microscope. J Conserv Dent 2013; 16(4): 352-5. [http://dx.doi.org/10.4103/0972-0707.114365] [PMID: 23956540]

[68] Lee P, Tan KS. Effects of Epigallocatechin gallate against Enterococcus faecalis biofilm and virulence. Arch Oral Biol 2015; 60(3): 393-9. [http://dx.doi.org/10.1016/j.archoralbio.2014.11.014] [PMID: 25526623]

[69] Seigler DS. Phytochemistry of Acaciaâ€’sensu lato. Biochem Syst Ecol 2003; 31: 845-73. [http://dx.doi.org/10.1016/S0305-1978(03)00082-6]

[70] Solomon-Wisdom G, Shittu G. In vitro antimicrobial and phytochemical activities of Acacia nilotica leaf extract. J Med Plants Res 2010; 4: $1232-4$.

[71] Satish S, Mohana D, Ranhavendra M, Raveesha K. Antifungal activity of some plant extracts against important seed borne pathogens of Aspergillus sp. Int J Agricul Technol 2007; 3: 109-19.

[72] Abdelrahman ME. The antibacterial, antiviral activities and phytochemical screening of some Sudanese medicinal plants. EurAsian J Bio Sci $2010 ; 8$.

[73] Shanab SM. Antioxidant and antibiotic activities of some seaweeds (Egyptian isolates). Int J Agric Biol 2007; 9: 220-5.

[74] Arora S, Kaur K, Kaur S. Indian medicinal plants as a reservoir of protective phytochemicals. Teratog Carcinog Mutagen 2003; (Suppl. 1)295-300. [http://dx.doi.org/10.1002/tcm.10055] [PMID: 12616620]

[75] Shah BH, Safdar B, Virani SS, Nawaz Z, Saeed SA, Gilani AH. The antiplatelet aggregatory activity of Acacia nilotica is due to blockade of calcium influx through membrane calcium channels. Gen Pharmacol 1997; 29(2): 251-5. [http://dx.doi.org/10.1016/S0306-3623(96)00413-2] [PMID: 9251908]

[76] Pai MB, Prashant GM, Murlikrishna KS, Shivakumar KM, Chandu GN. Antifungal efficacy of Punica granatum, Acacia nilotica, Cuminum cyminum and Foeniculum vulgare on Candida albicans: an in vitro study. Indian J Dent Res 2010; 21(3): 334-6. [http://dx.doi.org/10.4103/0970-9290.70792] [PMID: 20930339]

[77] Chaubal R, Deshpande V, Deshpande N. Methyl gallate, the medicinally important compound: A review. Electron J Environ Agric Food Chem 2005; 4: 956-62.

[78] Miller AB, Cates RG, Lawrence M, et al. The antibacterial and antifungal activity of essential oils extracted from Guatemalan medicinal plants. Pharm Biol 2015; 53(4): 548-54. [http://dx.doi.org/10.3109/13880209.2014.932391] [PMID: 25332067]

[79] Lee JH, Cho S, Paik HD, et al. Investigation on antibacterial and antioxidant activities, phenolic and flavonoid contents of some thai edible plants as an alternative for antibiotics. Asian-australas J Anim Sci 2014; 27(10): 1461-8. [http://dx.doi.org/10.5713/ajas.2013.13629] [PMID: 25178298]

[80] Bolhari B, Sharifian MR, Aminsobhani M, Monsef Esfehani HR, Tavakolian P. Assessing the efficacy of citrus aurantifolia extract on smear layer removal with scanning electron microscope. Iran Endod J 2012; 7(2): 88-97. [PMID: 23056125]

[81] Ateş DA, Erdoğrul ÖT. Antimicrobial activities of various medicinal and commercial plant extracts. Turk J Biol 2003; $27: 157-62$.

[82] Saeedi M, Morteza-Semnani K, Ghoreishi MR. The treatment of atopic dermatitis with licorice gel. J Dermatolog Treat 2003; 14(3): 153-7. 
[http://dx.doi.org/10.1080/09546630310014369] [PMID: 14522625]

[83] Sabouri Ghannad M, Mohammadi A, Safiallahy S, Faradmal J, Azizi M, Ahmadvand Z. The Effect of Aqueous Extract of Glycyrrhiza glabra on Herpes Simplex Virus 1. Jundishapur J Microbiol 2014; 7(7): e11616. [http://dx.doi.org/10.5812/jjm.11616] [PMID: 25368801]

[84] Shebl RI, Amin MA, Emad-Eldin A, et al. Antiviral activity of liquorice powder extract against varicella zoster virus isolated from Egyptian patients. Chang Gung Med J 2012; 35(3): 231-9. [PMID: 22735054]

[85] Badr AE, Omar N, Badria FA. A laboratory evaluation of the antibacterial and cytotoxic effect of Liquorice when used as root canal medicament. Int Endod J 2011; 44(1): 51-8. [http://dx.doi.org/10.1111/j.1365-2591.2010.01794.x] [PMID: 20812941]

[86] Haraguchi H, Tanimoto K, Tamura Y, Mizutani K, Kinoshita T. Mode of antibacterial action of retrochalcones from Glycyrrhiza inflata. Phytochemistry 1998; 48(1): 125-9.

[http://dx.doi.org/10.1016/S0031-9422(97)01105-9] [PMID: 9621457]

[87] Rajan S, Thirunalasundari T, Jeeva S. Anti-enteric bacterial activity and phytochemical analysis of the seed kernel extract of Mangifera indica Linnaeus against Shigella dysenteriae (Shiga, corrig.) Castellani and Chalmers. Asian Pac J Trop Med 2011; 4(4): 294-300. [http://dx.doi.org/10.1016/S1995-7645(11)60089-8] [PMID: 21771473]

[88] Shah KA, Patel MB, Patel RJ, Parmar PK. Mangifera indica (mango). Pharmacogn Rev 2010; 4(7): 42-8. [http://dx.doi.org/10.4103/0973-7847.65325] [PMID: 22228940]

[89] Subbiya A, Mahalakshmi K, Pushpangadan S, Padmavathy K, Vivekanandan P, Sukumaran VG. Antibacterial efficacy of Mangifera indica L. kernel and Ocimum sanctum L. leaves against Enterococcus faecalis dentinal biofilm. J Conserv Dent 2013; 16(5): 454-7. [http://dx.doi.org/10.4103/0972-0707.117507] [PMID: 24082577]

[90] Malekzadeh F, Ehsanifar H, Shahamat M, Levin M, Colwell RR. Antibacterial activity of black myrobalan (Terminalia chebula Retz) against Helicobacter pylori. Int J Antimicrob Agents 2001; 18(1): 85-8 [http://dx.doi.org/10.1016/S0924-8579(01)00352-1] [PMID: 11463533]

[91] Kumar M, Agarwal R, Dey S, Rai V, Johnson B. Antimicrobial activity of aqueous extract of Terminalia chebula Retz. On Gram-Positive and Gram-Negative micro-organisms. Int J Curr Pharmaceutical Res 2009; 1: 56-60.

[92] Rekha V, Jayamathi, RamaKrishnan , et al. Anti cariogenic effect of terminalia chebula. J Clin Diagn Res 2014; 8(8): ZC51-4. [PMID: 25302268]

[93] Chang CL, Lin CS. Phytochemical composition, antioxidant activity, and neuroprotective effect of terminalia chebula retzius extracts. Evid Based Complement Alternat Med 2012. 2012: 125247

[94] Vinothkumar TS, Rubin MI, Balaji L, Kandaswamy D. In vitro evaluation of five different herbal extracts as an antimicrobial endodontic irrigant using real time quantitative polymerase chain reaction. J Conserv Dent 2013; 16(2): 167-70. [http://dx.doi.org/10.4103/0972-0707.108208] [PMID: 23716972]

[95] Alipour G, Dashti S, Hosseinzadeh H. Review of pharmacological effects of Myrtus communis L. and its active constituents. Phytother Res 2014; 28(8): 1125-36

[http://dx.doi.org/10.1002/ptr.5122] [PMID: 24497171]

[96] Zomorodian K, Moein M, Lori ZG, et al. Chemical composition and antimicrobial activities of the essential oil from Myrtus communis leaves. J Essential Oil Bear Plants 2013; 16: 76-84 [http://dx.doi.org/10.1080/0972060X.2013.764183]

[97] Mohammadi R. MIR HES, Shadzi S, MOATAR F. Antifungal activity of Myrtus Communis L. esssential oil against clinical isolates of Aspergillus. J Isfahan Med Sch 2008.

[98] Aleksic V, Knezevic P. Antimicrobial and antioxidative activity of extracts and essential oils of Myrtus communis L. Microbiol Res 2014; 169(4): 240-54 [http://dx.doi.org/10.1016/j.micres.2013.10.003] [PMID: 24291016]

[99] Aidi Wannes W, Mhamdi B, Sriti J, et al. Antioxidant activities of the essential oils and methanol extracts from myrtle (Myrtus communis var. italica L.) leaf, stem and flower. Food Chem Toxicol 2010; 48(5): 1362-70. [http://dx.doi.org/10.1016/j.fct.2010.03.002] [PMID: 20211674]

[100] Feisst C, Franke L, Appendino G, Werz O. Identification of molecular targets of the oligomeric nonprenylated acylphloroglucinols from Myrtus communis and their implication as anti-inflammatory compounds. J Pharmacol Exp Ther 2005; 315(1): 389-96. [http://dx.doi.org/10.1124/jpet.105.090720] [PMID: 16014754]

[101] Tretiakova I, Blaesius D, Maxia L, et al. Myrtucommulone from Myrtus communis induces apoptosis in cancer cells via the mitochondrial pathway involving caspase-9. Apoptosis 2008; 13(1): 119-31. [http://dx.doi.org/10.1007/s10495-007-0150-0] [PMID: 17955373]

[102] Elfellah MS, Akhter MH, Khan MT. Anti-hyperglycaemic effect of an extract of Myrtus communis in streptozotocin-induced diabetes in mice. J Ethnopharmacol 1984; 11(3): 275-81.

[http://dx.doi.org/10.1016/0378-8741(84)90073-4] [PMID: 6482478] 
[103] Nabavizadeh M, Abbaszadegan A, Gholami A, et al. Chemical constituent and antimicrobial effect of essential oil from Myrtus communis leaves on microorganisms involved in persistent endodontic infection compared to two common endodontic irrigants: An in vitro study. $\mathrm{J}$ Conserv Dent 2014; 17(5): 449-53.

[http://dx.doi.org/10.4103/0972-0707.139836] [PMID: 25298646]

[104] Lis-Balchin M, Deans SG, Eaglesham E. Relationship between bioactivity and chemical composition of commercial essential oils. Flavour Fragrance J 1998; 13: 98-104. [http://dx.doi.org/10.1002/(SICI)1099-1026(199803/04)13:2<98::AID-FFJ705>3.0.CO;2-B]

[105] Ganguli S. Neem: A therapeutic for all seasons. Curr Sci 2002; 82: 1304.

[106] Okpanyi SN, Ezeukwu GC. Anti-inflammatory and antipyretic activities of Azadirachta indica. Planta Med 1981; 41(1): 34-9. [http://dx.doi.org/10.1055/s-2007-971670] [PMID: 6972048]

[107] Fabry W, Okemo PO, Ansorg R. Antibacterial activity of East African medicinal plants. J Ethnopharmacol 1998; 60(1): 79-84. [http://dx.doi.org/10.1016/S0378-8741(97)00128-1] [PMID: 9533435]

[108] Mahmoud DA, Hassanein NM, Youssef KA, Abou Zeid MA. Antifungal activity of different neem leaf extracts and the nimonol against some important human pathogens. Braz J Microbiol 2011; 42(3): 1007-16. [http://dx.doi.org/10.1590/S1517-83822011000300021] [PMID: 24031718]

[109] Upadhyay SN, Dhawan S, Garg S, Talwar GP. Immunomodulatory effects of neem (Azadirachta indica) oil. Int J Immunopharmacol 1992; 14(7): 1187-93. [http://dx.doi.org/10.1016/0192-0561(92)90054-O] [PMID: 1452404]

[110] Dutta A, Kundabala M. Antimicrobial efficacy of endodontic irrigants from Azadirachta indica: An in vitro study. Acta Odontol Scand 2013; 71(6): 1594-8. [http://dx.doi.org/10.3109/00016357.2013.780290] [PMID: 23638768]

[111] Dutta A, Kundabala M. Comparative anti-microbial efficacy of Azadirachta indica irrigant with standard endodontic irrigants: A preliminary study. J Conserv Dent 2014; 17(2): 133-7. [http://dx.doi.org/10.4103/0972-0707.128047] [PMID: 24778508]

[112] Mistry KS, Sanghvi Z, Parmar G, Shah S. The antimicrobial activity of Azadirachta indica, Mimusops elengi, Tinospora cardifolia, Ocimum sanctum and $2 \%$ chlorhexidine gluconate on common endodontic pathogens: An in vitro study. Eur J Dent 2014; 8(2): 172-7. [http://dx.doi.org/10.4103/1305-7456.130591] [PMID: 24966766]

[113] Prabhat A, Navneet CA. Evaluation of antimicrobial activity of six medicinal plants against dental pathogens. Report Opinion 2010; 2 : 37-42.

[114] Younos C, Rolland A, Fleurentin J, Lanhers MC, Misslin R, Mortier F. Analgesic and behavioural effects of Morinda citrifolia. Planta Med 1990; 56(5): 430-4. [http://dx.doi.org/10.1055/s-2006-961004] [PMID: 1981810]

[115] Candida T, França JP, Chaves AL, et al. Evaluation of antitumoral and antimicrobial activity of Morinda lcitrifolia L. grown in Southeast Brazil. Acta Cir Bras 2014; 29(Suppl. 2): 10-4

[http://dx.doi.org/10.1590/S0102-86502014001400003] [PMID: 25229508]

[116] Brown AC. Anticancer activity of Morinda citrifolia (Noni) fruit: a review. Phytother Res 2012; 26(10): $1427-40$. [PMID: 22344842]

[117] Wang MY, West BJ, Jensen CJ, et al. Morinda citrifolia (Noni): a literature review and recent advances in Noni research. Acta Pharmacol Sin 2002; 23(12): 1127-41. [PMID: 12466051]

[118] Murray PE, Farber RM, Namerow KN, Kuttler S, Garcia-Godoy F. Evaluation of Morinda citrifolia as an endodontic irrigant. J Endod 2008; 34(1): 66-70. [http://dx.doi.org/10.1016/j.joen.2007.09.016] [PMID: 18155496]

[119] Das A, Kottoor J, Mathew J, Kumar S, George S. Dentine microhardness changes following conventional and alternate irrigation regimens: An in vitro study. J Conserv Dent 2014; 17(6): 546-9. [http://dx.doi.org/10.4103/0972-0707.144592] [PMID: 25506142]

[120] Cho JY, Choi GJ, Son SW, et al. Isolation and antifungal activity of lignans from Myristica fragrans against various plant pathogenic fungi. Pest Manag Sci 2007; 63(9): 935-40. [http://dx.doi.org/10.1002/ps.1420] [PMID: 17659535]

[121] Shafiei Z, Shuhairi NN, Md Fazly Shah Yap N, Harry Sibungkil CA, Latip J. Antibacterial Activity of Myristica fragrans against Oral Pathogens. Evid Based Complement Alternat Med 2012. 2012: 825362.

[122] Moinuddin G, Devi K, Kumar Khajuria D. Evaluation of the anti-depressant activity of Myristica fragrans (Nutmeg) in male rats. Avicenna J Phytomed 2012; 2(2): 72-8. [PMID: 25050233]

[123] Patil SB, Ghadyale VA, Taklikar SS, Kulkarni CR, Arvindekar AU. Insulin secretagogue, alpha-glucosidase and antioxidant activity of some selected spices in streptozotocin-induced diabetic rats. Plant Foods Hum Nutr 2011; 66(1): 85-90. [http://dx.doi.org/10.1007/s11130-011-0215-7] [PMID: 21437656] 
[124] Piaru SP, Mahmud R, Abdul Majid AM, Mahmoud Nassar ZD. Antioxidant and antiangiogenic activities of the essential oils of Myristica fragrans and Morinda citrifolia. Asian Pac J Trop Med 2012; 5(4): 294-8. [http://dx.doi.org/10.1016/S1995-7645(12)60042-X] [PMID: 22449521]

[125] Zibadi S, Argüelles M, Watson R. Passion fruit (Passiflora edulis): composition, efficacy and safety. In: Watson R, Preedy V, Eds. Botanical Medicine in Clinical Practice. UK: CABI 2008.

[126] Nicolls JM, Birner J, Forsell P. Passicol, an antibacterial and antifungal agent produced by Passiflora plant species: qualitative and quantitative range of activity. Antimicrob Agents Chemother 1973; 3(1): 110-7. [http://dx.doi.org/10.1128/AAC.3.1.110] [PMID: 4790567]

[127] Konta EM, Almeida MR, do Amaral CL, et al. Evaluation of the antihypertensive properties of yellow passion fruit pulp (Passiflora edulis Sims f. flavicarpa Deg.) in spontaneously hypertensive rats. Phytother Res 2014; 28(1): 28-32. [http://dx.doi.org/10.1002/ptr.4949] [PMID: 23436457]

[128] Silva DC, Freitas AL, Pessoa CD, et al. Pectin from Passiflora edulis shows anti-inflammatory action as well as hypoglycemic and hypotriglyceridemic properties in diabetic rats. J Med Food 2011; 14(10): 1118-26. [http://dx.doi.org/10.1089/jmf.2010.0220] [PMID: 21554121]

[129] Jayahari NK, Niranjan NT, Kanaparthy A. The efficacy of passion fruit juice as an endodontic irrigant compared with sodium hypochlorite solution: an in vitro study. J Investig Clin Dent 2014; 5(2): 154-60. [http://dx.doi.org/10.1111/jicd.12023] [PMID: 23355285]

[130] Prakash S, Shelke AU. Role of Triphala in dentistry. J Indian Soc Periodontol 2014; 18(2): 132-5. [http://dx.doi.org/10.4103/0972-124X.131299] [PMID: 24872616]

[131] Shakouie S, Eskandarinezhad M, Gasemi N, Milani AS, Samiei M, Golizadeh S. An in vitro comparison of the antibacterial efficacy of triphala with different concentrations of sodium hypochlorite. Iran Endod J 2014; 9(4): 287-9. [PMID: 25386211]

[132] Prabhakar J, Balagopal S, Priya MS, Selvi S, Senthilkumar M. Evaluation of antimicrobial efficacy of Triphala (an Indian Ayurvedic herbal formulation) and $0.2 \%$ chlorhexidine against Streptococcus mutans biofilm formed on tooth substrate: an in vitro study. Indian J Dent Res 2014; 25(4): 475-9. [http://dx.doi.org/10.4103/0970-9290.142539] [PMID: 25307912]

[133] Chainani SH, Siddana S, Reddy C, Manjunathappa TH, Manjunath M, Rudraswamy S. Antiplaque and antigingivitis efficacy of triphala and chlorhexidine mouthrinse among schoolchildren - a cross-over, double-blind, randomised controlled trial. Oral Health Prev Dent 2014; 12(3): 209-17. [PMID: 25197734]

[134] Jagtap AG, Karkera SG. Potential of the aqueous extract of Terminalia chebula as an anticaries agent. J Ethnopharmacol 1999; 68(1-3): 299-306.

[http://dx.doi.org/10.1016/S0378-8741(99)00058-6] [PMID: 10624892]

[135] Abraham S, Kumar MS, Sehgal PK, Nitish S, Jayakumar ND. Evaluation of the inhibitory effect of triphala on PMN-type matrix metalloproteinase (MMP-9). J Periodontol 2005; 76(4): 497-502. [http://dx.doi.org/10.1902/jop.2005.76.4.497] [PMID: 15857087]

[136] Saharkhiz MJ, Kamyab AA, Kazerani NK, Zomorodian K, Pakshir K, Rahimi MJ. Chemical compositions and antimicrobial activities of ocimum sanctum L. essential oils at different harvest stages. Jundishapur J Microbiol 2015; 8(1): e13720. [PMID: 25763132]

[137] Khan V, Najmi AK, Akhtar M, Aqil M, Mujeeb M, Pillai KK. A pharmacological appraisal of medicinal plants with antidiabetic potential. J Pharm Bioallied Sci 2012; 4(1): 27-42

[http://dx.doi.org/10.1016/j.jpba.2011.09.019] [PMID: 22368396]

[138] Baliga MS, Jimmy R, Thilakchand KR, et al. Ocimum sanctum L (Holy Basil or Tulsi) and its phytochemicals in the prevention and treatment of cancer. Nutr Cancer 2013; 65(Suppl. 1): 26-35. [http://dx.doi.org/10.1080/01635581.2013.785010] [PMID: 23682780]

[139] Banerjee A, Nigam SS. Antimicrobial efficacy of the essential oil of Curcuma longa. Indian J Med Res 1978; 68: 864-6. [PMID: 730260]

[140] Fan Z, Yao J, Li Y, Hu X, Shao H, Tian X. Anti-inflammatory and antioxidant effects of curcumin on acute lung injury in a rodent model of intestinal ischemia reperfusion by inhibiting the pathway of NF-Kb. Int J Clin Exp Pathol 2015; 8(4): 3451-9. [PMID: 26097529]

[141] Sarkar R, Mukherjee A, Mukherjee S, Biswas R, Biswas J, Roy M. Curcumin augments the efficacy of antitumor drugs used in leukemia by modulation of heat shock proteins via HDAC6. J Environ Pathol Toxicol Oncol 2014; 33(3): 247-63. [http://dx.doi.org/10.1615/JEnvironPatholToxicolOncol.2014010913] [PMID: 25272063]

[142] Schneider C, Gordon ON, Edwards RL, Luis PB. Degradation of curcumin: from mechanism to biological implications. J Agric Food Chem 2015; 63(35): 7606-14 [http://dx.doi.org/10.1021/acs.jafc.5b00244] [PMID: 25817068]

[143] Neelakantan P, Subbarao C, Sharma S, Subbarao CV, Garcia-Godoy F, Gutmann JL. Effectiveness of curcumin against Enterococcus faecalis 
biofilm. Acta Odontol Scand 2013; 71(6): 1453-7.

[http://dx.doi.org/10.3109/00016357.2013.769627] [PMID: 23394209]

[144] Pileggi G, Wataha JC, Girard M, et al. Blue light-mediated inactivation of Enterococcus faecalis in vitro. Photodiagn Photodyn Ther 2013; 10(2): 134-40.

[http://dx.doi.org/10.1016/j.pdpdt.2012.11.002] [PMID: 23769279]

[145] Bulit F, Grad I, Manoil D, et al. Antimicrobial activity and cytotoxicity of 3 photosensitizers activated with blue light. J Endod 2014; 40(3): 427-31.

[http://dx.doi.org/10.1016/j.joen.2013.12.001] [PMID: 24565665]

[146] Praveenkumar S. Mandroli, Bhat K. An in-vitro evaluation of antibacterial activity of curcumin against common endodontic bacteria. J Appl Pharm Sci 2013; 3: 106-8.

[147] Neelakantan P, Cheng CQ, Ravichandran V, et al. Photoactivation of curcumin and sodium hypochlorite to enhance antibiofilm efficacy in root canal dentin. Photodiagn Photodyn Ther 2015; 12(1): 108-14. [http://dx.doi.org/10.1016/j.pdpdt.2014.10.011] [PMID: 25462576]

[148] Sajed H, Sahebkar A, Iranshahi M. Zataria multiflora Boiss. (Shirazi thyme)--an ancient condiment with modern pharmaceutical uses. J Ethnopharmacol 2013; 145(3): 686-98. [http://dx.doi.org/10.1016/j.jep.2012.12.018] [PMID: 23266333]

[149] Abbaszadegan A, Sahebi S, Gholami A, et al. Time-dependent antibacterial effects of Aloe vera and Zataria multiflora plant essential oils compared to calcium hydroxide in teeth infected with Enterococcus faecalis. J Investig Clin Dent 2014; 5: 1-9. [PMID: 25187255]

(C) Venkateshbabu et al.; Licensee Bentham Open.

This is an open access article licensed under the terms of the Creative Commons Attribution-Non-Commercial 4.0 International Public License (CC BY-NC 4.0) (https://creativecommons.org/licenses/by-nc/4.0/legalcode), which permits unrestricted, non-commercial use, distribution and reproduction in any medium, provided the work is properly cited. 